\title{
Tyrosine-Protein Kinase JAK3
}

National Cancer Institute

\section{Source}

National Cancer Institute. Tyrosine-Protein Kinase JAK3. NCI Thesaurus. Code C28492.

Tyrosine-protein kinase JAK3 (1124 aa, $125 \mathrm{kDa})$ is encoded by the human JAK3 gene.

This protein is involved in T-cell development, immunity, signaling and tyrosine phosphorylation. 